\title{
Gentamicin in Esch. coli Gastroenteritis
}

\author{
M. COETZEE and P. M. LEARY \\ From the Red Cross War Memorial Children's Hospital, and the Department of Paediatrics and Child Health, University \\ of Cape Town, S. Africa
}

\begin{abstract}
Coetzee, M., and Leary, P. M. (1971). Archives of Disease in Childhood, 46, 646. Gentamicin in Esch. coli gastroenteritis. A study has been made of 90 Cape Town infants who presented with acute gastroenteritis and from whose stools enteropathic Escherichia coli were isolated. These children were treated with combined oral and parenteral gentamicin. On this regimen $92 \%$ of the infants recovered rapidly and only one died.
\end{abstract}

Gastroenteritis is the commonest disease affecting non-European infants and children in Cape Town in the summer. At the Red Cross War Memorial Children's Hospital, patients with gastroenteritis who are clinically dehydrated are admitted to a resuscitation unit in the outpatient department. Response to standard treatment is in general good, and most patients are discharged after 12 to 24 hours. During 1969, 11,991 children were treated. It is not practicable to obtain routine stool culture in every case admitted to the unit. However, figures quoted by Watson, Leary, and Hartley (1970), and an analysis of all stools submitted for culture in a 3-month period (see Table V), suggest that in the majority of cases no pathogen would be isolated. This claim is supported by reports from elsewhere (British Medical Journal, 1968; Ramsay, 1968; Moffet, Shulenberger, and Burkholder, 1968).

Over the past 5 years attention has focused on a group of infants whose illness did not conform to the general pattern. The majority of these infants were only a few months old and none was over 1 year. Almost two-thirds were below the 3rd Boston weight centile, and there was often a history of morbidity in the neonatal period, and subsequent failure to thrive with recurrent gastroenteritis. The infants were seldom breast-fed. Stools were copious and extremely watery, with a peculiar pungent odour which some observers felt was almost diagnostic of the condition. Microscopical examination showed that pus cells were present only infrequently. Vomiting was persistent, the abdomen often distended, and an impression of toxicity evident. The course of the illness was protracted and there was no response to the stan-

Received 30 March 1971. dard regimen of treatment. Mortality was high. As soon as it became policy to request special stool cultures for enteropathic Escherichia coli (EEC) whenever this clinical picture was encountered in the resuscitation unit, the aetiology became clearly established.

This paper is a study of the management of 90 cases of gastroenteritis which conformed clinically to the description outlined above, and which were treated during the spring months of September, October, and November 1969.

\section{Treatment}

Initial fluid replacement was given according to clinical assessment of dehydration, a child adjudged to be $5 \%$ dehydrated receiving $50 \mathrm{ml} / \mathrm{kg}$ body weight and one adjudged to be $10 \%$ dehydrated receiving twice this volume. A standard solution of half-strength Darrow's in $2 \frac{1}{2} \%$ glucose was used for replacement and maintenance purposes. The latter volume was calculated according to the formula $150 \mathrm{ml} / \mathrm{kg}$ per day. Because of the general prevalence of protein-calorie malnutrition, it is the practice in the resuscitation room to resume oral feeds with undiluted milk after 24 hours, with corresponding reduction in the volume of intravenous fluids. Oral feeds are withheld if vomiting persists. As soon as the laboratory reported isolation of EEC, treatment with gentamicin was started. It was administered orally in four daily doses calculated according to the formula, $4 \mathrm{mg} / \mathrm{kg}$ body weight per day, and also by intramuscular injection in 2 daily doses according to the formula: $2 \mathrm{mg} / \mathrm{kg}$ body weight per day. Simultaneous oral and intramuscular administration was maintained for 5 days. The child was then discharged from the resuscitation unit and was asked to reattend as an outpatient 2 days later so that final clinical assessment could be made. Because of the large numbers of infants managed in the resuscitation room it was not feasible to obtain stool cultures on the completion of the 
gentamicin course, and cure was judged on clinical grounds.

\section{Results}

Some details of the infants are given in Table I. The racial distribution of cases merely reflects the proportions of Coloured (mixed blood) and of African patients who attend the hospital. European children have not been considered in this study. The average age of patients was $4 \cdot 3$ months and $64 \%$ were below the 3rd Boston weight centile (Nelson, Vaughan, and McKay, 1969).

TABLE I

Sex, Race, and Mean Age of Infants

\begin{tabular}{|c|c|c|c|c|c|c|}
\hline \multirow{2}{*}{ Total } & \multicolumn{2}{|c|}{ Sex } & \multicolumn{2}{|c|}{ Race } & \multirow{2}{*}{$\begin{array}{c}\text { Mean } \\
\text { Age } \\
\text { (mth) }\end{array}$} & \multirow{2}{*}{$\begin{array}{c}<3 \text { rd } \\
\text { Centile }\end{array}$} \\
\hline & $\mathbf{M}$ & $\mathbf{F}$ & Coloured & African & & \\
\hline 90 & 53 & 37 & 74 & 16 & $4 \cdot 3$ & 58 \\
\hline
\end{tabular}

The average stay in the resuscitation unit was 9.3 days (Table II). Since treatment with gentamicin was in every case maintained for 5 days, on average, infants spent more than 4 days in the resuscitation unit before the organism was isolated from stool specimens, and specific treatment initiated. Clinical response to gentamicin was usually dramatic with rapid decrease in the number of stools. Within 36 hours most infants were able to maintain hydration without intravenous supplementation. On discharge, stools were normal in frequency and consistency, and the infant was retaining milk feeds adequate for his weight and age. The average increase in weight during treatment in the resuscitation ward was $531 \mathrm{~g}$. $61 \%$ of children were seen again, usually 2 days after discharge, and were found to be in satisfactory condition.

\section{TABLE II}

Average Duration of Illness in Days

\begin{tabular}{llllll}
\hline In resuscitation room & $\ldots$ & $\ldots$ & $\ldots$ & $\ldots$ & $9 \cdot 3$ \\
On intravenous therapy & $\ldots$ & $\ldots$ & $\ldots$ & $\ldots$ & $3 \cdot 6$ \\
On intravenous therapy after & gentamicin & $\ldots$ & $\ldots$ & $1 \cdot 5$ \\
\hline
\end{tabular}

The outcome of treatment is indicated in Table III. One child died despite a full course of treatment with gentamicin. Necropsy revealed only the features of severe gastroenteritis. One mother absconded from the unit with her child before the course of treatment had been completed. 5 children were admitted to hospital wards and so did not complete their treatment in the resuscitation ward.
One of these had concomitant congenital heart disease and another had whooping cough. The remaining 3 failed to respond in the rapid manner demonstrated by the majority.

\section{TABLE III}

\begin{tabular}{|c|c|c|c|c|c|c|c|}
\hline \multicolumn{5}{|c|}{ Discharged from resuscitation ward } & . & . & \multirow{4}{*}{$\begin{array}{r}83 \\
5 \\
1 \\
1\end{array}$} \\
\hline Admitted to & hos & & . & . & . & . & \\
\hline Died $\ldots$ & . & . & . & . & . & . & \\
\hline Absconded & - & . & . & . & . & - & \\
\hline Total .. & . & . & $\cdots$ & . & $\cdots$ & . & 90 \\
\hline
\end{tabular}

Serotypes of EEC isolated are indicated in Table IV. With one exception all isolates were sensitive to gentamicin. $91 \%$ were also sensitive to both colistin and nalidixic acid. $7 \%$ were resistant to nalidixic acid and only $1 \%$ to colistin. Sensitivities to other antibiotics were found to vary widely, even within a given serotype.

\section{Discussion}

The role of certain serological types of EEC in the aetiology of diarrhoea among neonates has been recognized for many years. Nelson's Textbook of Pediatrics (Nelson et al., 1969) mentions that 10 different serological types have been incriminated in various epidemics. The epidemic in 1967 on Tees-side, in which 14 of the affected infants died, was due to a strain of Esch. coli 0128 , resistant to neomycin and a number of other antibiotics (Lancet, 1968). In recent years smaller epidemics have been reported from Winchester (Hughes, Greaves, and Bettelheim, 1968) and Manchester (Lancet, 1969). Clinical findings in the latter outbreak closely resembled those observed at Red Cross Hospital.

The present study indicates that diarrhoea due to EEC is endemic rather than epidemic among very young infants in Cape Town. The fact that at any one time there were infants in the resuscitation room infected with a variety of serotypes suggests that cross-infection was not a major feature. Studies by Ironside, Tuxford, and Heyworth (1970) in Manchester, and Moffet et al. (1968) in the United States suggest that infection occurs sporadically in other centres too. Ironside et al. (1970) comment that those infants with diarrhoea from whose stools EEC was cultured differed in no way from those whose diarrhoea was due to other pathogens. This statement is surprising both in the light of our clinical findings and considering the high mortality recorded when epidemics have occurred. It merits further consideration. 
TABLE IV

Serotypes Isolated and Antibiotic Sensitivities

\begin{tabular}{|c|c|c|c|c|c|c|c|c|c|c|}
\hline \multirow{2}{*}{ Serotype } & \multirow{2}{*}{ No. } & \multicolumn{9}{|c|}{ Sensitivity } \\
\hline & & $\begin{array}{c}\text { Genta- } \\
\text { micin }\end{array}$ & Colistoin & $\begin{array}{c}\text { Naladixic } \\
\text { Acid }\end{array}$ & Neomycin & $\begin{array}{l}\text { Kana- } \\
\text { mycin }\end{array}$ & $\begin{array}{l}\text { Tetra- } \\
\text { cycline }\end{array}$ & \begin{tabular}{|l|}
$\begin{array}{l}\text { Chloram- } \\
\text { phenicol }\end{array}$ \\
\end{tabular} & $\begin{array}{c}\text { Strepto- } \\
\text { mycin }\end{array}$ & Ampicillin \\
\hline $0 \cdot 119 / \mathrm{B} 14$ & $\begin{array}{l}1 \\
1 \\
2 \\
1 \\
\end{array}$ & $\begin{array}{l}+ \\
+ \\
+ \\
+ \\
\end{array}$ & $\begin{array}{l}+ \\
+ \\
+ \\
+ \\
\end{array}$ & $\begin{array}{l}+ \\
+ \\
+ \\
+ \\
\end{array}$ & + & $\begin{array}{l}+ \\
+ \\
+ \\
\end{array}$ & $\begin{array}{l}+ \\
+\end{array}$ & $\begin{array}{l}+ \\
+ \\
+\end{array}$ & & + \\
\hline $0 \cdot 111 / \mathbf{B} 4$ & $\begin{array}{l}1 \\
2 \\
1 \\
7 \\
7 \\
1 \\
1 \\
1 \\
1\end{array}$ & $\begin{array}{l}+ \\
+ \\
+ \\
+ \\
+ \\
+ \\
+ \\
+ \\
+ \\
\end{array}$ & $\begin{array}{l}+ \\
+ \\
+ \\
+ \\
+ \\
+ \\
+ \\
+ \\
\end{array}$ & $\begin{array}{l}+ \\
+ \\
+ \\
+ \\
+ \\
+ \\
+ \\
+\end{array}$ & $\begin{array}{l}+ \\
+ \\
+\end{array}$ & $\begin{array}{l}+ \\
+ \\
+ \\
+ \\
+ \\
+\end{array}$ & $\begin{array}{l}+ \\
+ \\
+ \\
+\end{array}$ & + & $\begin{array}{llll}+ & & l & 0\end{array}$ & $\begin{array}{l}+ \\
+ \\
+\end{array}$ \\
\hline $0 \cdot 125 /$ B 15 & $\begin{array}{l}2 \\
1 \\
1 \\
\end{array}$ & $\begin{array}{l}+ \\
+ \\
+ \\
\end{array}$ & $\begin{array}{l}+ \\
+ \\
+ \\
\end{array}$ & $\begin{array}{l}+ \\
+ \\
+\end{array}$ & + & + & & + & + & \\
\hline $0 \cdot 26 / \mathrm{B} 6$ & $\begin{array}{l}2 \\
1 \\
1 \\
\end{array}$ & $\begin{array}{l}+ \\
+ \\
+\end{array}$ & $\begin{array}{l}+ \\
+ \\
+ \\
\end{array}$ & $\begin{array}{l}+ \\
+\end{array}$ & + & $\begin{array}{l}+ \\
+\end{array}$ & $\begin{array}{l}+ \\
+\end{array}$ & $\begin{array}{l}+ \\
+ \\
+\end{array}$ & + & + \\
\hline $0 \cdot 127 / \mathrm{B} 8$ & $\begin{array}{l}1 \\
1 \\
1\end{array}$ & $\begin{array}{l}+ \\
+ \\
+ \\
\end{array}$ & $\begin{array}{l}+ \\
+ \\
+\end{array}$ & $\begin{array}{l}+ \\
+ \\
+ \\
\end{array}$ & $\begin{array}{l}+ \\
+\end{array}$ & + & & $\begin{array}{l}+ \\
+\end{array}$ & & + \\
\hline $0.55 / \mathrm{B} 5$ & 2 & + & + & + & + & + & + & + & + & + \\
\hline $0 \cdot 126 /$ B 16 & $\begin{array}{l}1 \\
1 \\
5 \\
1 \\
1 \\
1 \\
3 \\
1 \\
3 \\
1 \\
1 \\
2 \\
1 \\
2 \\
1 \\
1 \\
1 \\
1 \\
1 \\
\end{array}$ & $\begin{array}{l}+ \\
+ \\
+ \\
+ \\
+ \\
+ \\
+ \\
+ \\
+ \\
+ \\
+ \\
+ \\
+ \\
+ \\
+ \\
+ \\
+ \\
+ \\
+\end{array}$ & $\begin{array}{l}+ \\
+ \\
+ \\
+ \\
+ \\
+ \\
+ \\
+ \\
+ \\
+ \\
+ \\
+ \\
+ \\
+ \\
+ \\
+ \\
+ \\
+ \\
+\end{array}$ & $\begin{array}{l}+ \\
+ \\
+ \\
+ \\
+ \\
+ \\
+ \\
+ \\
+ \\
+ \\
+ \\
+ \\
+ \\
+ \\
+ \\
+ \\
+ \\
+ \\
+ \\
+\end{array}$ & $\begin{array}{l}+ \\
+ \\
+ \\
+\end{array}$ & $\begin{array}{l}+ \\
+ \\
+ \\
+ \\
+ \\
+ \\
+ \\
+ \\
+ \\
+ \\
+\end{array}$ & $\begin{array}{l}+ \\
+ \\
+ \\
+ \\
+ \\
+ \\
+\end{array}$ & $\begin{array}{l}+ \\
+ \\
+ \\
+ \\
+ \\
+ \\
+ \\
+\end{array}$ & + & $\begin{array}{l}+ \\
+ \\
+ \\
+ \\
+ \\
+\end{array}$ \\
\hline $0 \cdot 128 / \mathrm{B} 12$ & $\begin{array}{l}1 \\
1 \\
3 \\
1 \\
\end{array}$ & $\begin{array}{l}+ \\
+ \\
+ \\
+ \\
\end{array}$ & $\begin{array}{l}+ \\
+ \\
+ \\
+ \\
\end{array}$ & $\begin{array}{l}+ \\
+ \\
+ \\
+ \\
\end{array}$ & $\begin{array}{l}+ \\
+ \\
\end{array}$ & $\begin{array}{l}+ \\
+ \\
\end{array}$ & $\begin{array}{l}+ \\
+\end{array}$ & $\begin{array}{l}+ \\
+\end{array}$ & $\begin{array}{l}+ \\
+\end{array}$ & $\begin{array}{l}+ \\
+\end{array}$ \\
\hline $0 \cdot 86 / B 7$ & $\begin{array}{l}1 \\
1 \\
9 \\
1 \\
1 \\
1 \\
1\end{array}$ & $\begin{array}{l}+ \\
+ \\
+ \\
+ \\
+ \\
+ \\
+\end{array}$ & $\begin{array}{l}+ \\
+ \\
+ \\
+ \\
+ \\
+ \\
+\end{array}$ & $\begin{array}{l}+ \\
+ \\
+ \\
+ \\
+ \\
+\end{array}$ & $\begin{array}{l}+ \\
+\end{array}$ & $\begin{array}{l}+ \\
+ \\
+ \\
+ \\
+\end{array}$ & $\begin{array}{l}+ \\
+\end{array}$ & $\begin{array}{l}+ \\
+ \\
+ \\
+\end{array}$ & + & $\begin{array}{l}+ \\
+\end{array}$ \\
\hline
\end{tabular}

Table $\mathrm{V}$ is an analysis of the reports of all stools submitted to the laboratory for examination during the three-month period of the study. A total of 147 stool specimens yielded cultures of EEC. Not all of these came from infants in the resuscitation room. 28 were seen in the outpatient department, but did not require treatment in the resuscitation room and have not been followed. The 90 infants 
TABLE V

Stool Isolates: September-November 1969

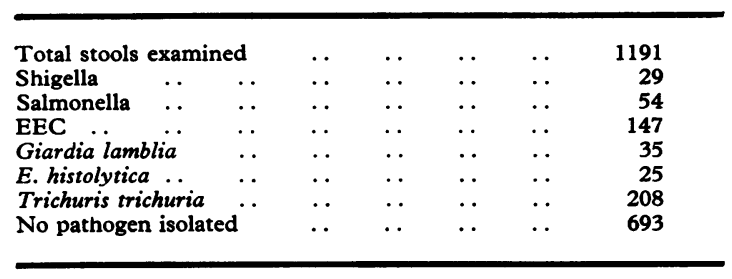

included in the study presented with the clinical picture of severe gastroenteritis described and these were treated with gentamicin. There were a further 29 children who were admitted to the resuscitation room for treatment of dehydration and from whose stools EEC were isolated. The clinical illness from which these infants suffered differed in no respect from that of the majority of infants in the resuscitation room and response to intravenous fluids and routine management was rapid. Gentamicin was not given to these infants. Many had already been discharged from the resuscitation room when the result of stool culture became known. Clearly these cases resemble those observed by Ironside et al. (1970). Though the clinical course differed strikingly from the 90 (gentamicin treated) severely affected infants, there was no difference in average age or nutritional status. The same strain of EEC was responsible in some infants for severe illness and in others for mild illness. Ramsay (1968) has stated that $2 \%$ of normal healthy infants carry EEC and in a study made by the Public Health Laboratory Service in Britain (1959) 15-20 per thousand in a sample of children between 0 and 5 years were found to carry EEC. It is known that many children recovering from attacks of EEC gastroenteritis become convalescent carriers. These observations suggest that the clinical consequences of infection depend upon a host factor rather than variations in virulence, and this hypothesis is strengthened by the finding in the present study that many of the severely affected infants had suffered perinatal morbidity and were below the 3rd centile.

The choice of antibiotic used deserves consideration. In the past an oral sulphonamide or nonabsorbable antibiotic has been administered to all children admitted to the resuscitation room with a view to sterilizing the contents of the gastrointestinal tract. This practice is difficult to justify and has been condemned (British Medical Journal, 1970). It has now been abandoned in the resuscitation unit, and clinical management is focused on the correction and maintenance of fluid and electrolyte balance. Where EEC is isolated from the stool it is felt that the use of an antibiotic is justified by the prolonged and often fatal course which the disease follows and the rapid response to an effective drug.

In this study sensitivity reports showed that the serotypes of EEC were resistant to many antibiotics (Table IV) and in practice choice was limited to gentamicin, colistin, and nalidixic acid. It was felt that a parenteral preparation was mandatory because of possible tissue invasion by EEC, and that this should be coupled with oral administration to sterilize the gastrointestinal system. Colistin is extremely poorly absorbed from the gastrointestinal tract and even after parenteral administration blood levels are low. A parenteral preparation of nalidixic acid is not available. Hence gentamicin became the drug of choice.

The parenteral dosage used was $2 \mathrm{mg} / \mathrm{kg}$ per day, and thought must be given to possible toxic effects. Gentamicin is known to be nephrotoxic in animals and vestibular damage has been reported in man. However, renal insufficiency, prolonged treatment, and combination with other ototoxic drugs were usual concomitants in reported cases (South African Medical Journal, 1968). The dosage used in this study was lower than the maximum currently recommended $(3 \mathrm{mg} / \mathrm{kg})$ to allow a safety margin in the event of some absorption from the intestine. Gentamicin has been available at Red Cross Hospital since 1965 and we are not aware of any case of vestibular disease which can be attributed to its use. We feel that the severity of the infection and the excellent therapeutic result achieved- $92 \%$ success and only 1 fatality-justify the slight risk taken in this respect.

Much has been written about the ability of EEC to acquire resistance by transfer of $R$ factors, and resistance to many antibiotics is a feature of this study. That EEC may eventually become resistant to gentamicin too, must be borne in mind. Studies at the Red Cross Hospital have shown the presence of serotypes which carry the $R$ factor. For this reason oral nalidixic acid is now being used to treat infections due to sensitive serotypes of EEC. Initial results show a less favourable response than that obtained from combined parenteral and oral gentamicin, but controlled studies must still be assessed. To date $98 \%$ of EEC serotypes are still sensitive to gentamicin.

We are grateful to Dr. C. E. Watson who conducted all the bacteriological studies. 


\section{REFERENCES}

British Medical fournal (1968). Leading article. Acute gastroenteritis, 1, 70.

British Medical fournal (1970). Leading article. Infantile gastroenteritis, 3, 2.

Hughes, M. H., Greaves, J. L., and Bettelheim, K. A. (1968). Infant diarrhoea due to Escherichia coli $091 \mathrm{~K}$ ? H7. Fournal of Clinical Pathology, 21, 387.

Ironside, A. G., Tuxford, A. F., and Heyworth, B. (1970). A survey of infantile gastroenteritis. British Medical fournal, 3, 20.

Lancet (1968). Gastro-enteritis on Tees-side, 1, 588.

Lancet (1969). Gastroenteritis at Booth Hall Children's Hospital, Manchester, 1, 843.

Moffet, H. L., Shulenberger, H. K., and Burkholder, E. R. (1968). Epidemiology and etiology of severe infantile diarrhea. Fournal of Pediatrics, 72, 1.

Nelson, W. E., Vaughan, V. C., and McKay, R. J. (1969). Textbook of Pediatrics, p. 405. Saunders, Philadelphia.
Public Health Laboratory Service (1959). Frequency of carriers of Salmonellae, Shigellae, and pathogenic coliform organisms in normal children under 5 years. Monthly Bulletin of the Ministry of Health and the Public-Health Laboratory Service, $18,86$.

Ramsay, A. M. (1968). Acute infective diarrhoea. British Medical fournal, 2, 347.

South African Medical fournal (1968). Leading article. Gentamicin, 42, 1.

Watson, C. E., Leary, P. M., and Hartley, P. S. (1970). Amoebiasis in Cape Town children. South African Medical fournal, 44, 419.

Correspondence to Dr. P. M. Leary, Department of Paediatrics and Child Health, University of Cape Town, Observatory, Cape, South Africa. 